\title{
Yersinia pseudotuberculosis
}

National Cancer Institute

\section{Source}

National Cancer Institute. Yersinia pseudotuberculosis. NCI Thesaurus. Code C86861.

A species of facultatively anaerobic, Gram negative, rod shaped bacteria in the phylum Proteobacteria. This species is motile, urease positive and negative for ornithine decarboxylase, oxidase, indole, and pyrazinamidase. It is able to ferment rhamnose, and melibiose but not cellobiose, sorbitol, sorbose, sucrose, fucose, or raffinose. Y. pseudotuberculosis is found in many animal hosts and is a pathogen that can cause gastroenteritis in humans and many types of zoonotic infections. 